\title{
Case report: bacterial gill disease in goldfish Carassias auratus
}

\author{
V. E. Ostland ${ }^{1}$, H. W. Ferguson ${ }^{1}$, R. M. W. Stevenson ${ }^{2}$ \\ ${ }^{1}$ Fish Pathology Laboratory, Department of Pathology, Ontario Veterinary College, ${ }^{2}$ Department of Microbiology,
} University of Guelph, Guelph, Ontario, Canada N1G 2W1

\begin{abstract}
Three separate outbreaks of bacterial gill disease (BGD) were diagnosed in goldfish Carassius auratus L. purchased as food for larger piscivorous fish. Histologically, the fish from all outbreaks had large numbers of filamentous bacteria associated with the gill tissue. One outbreak displayed a mild necrotizing response to the bacteria, suggesting BGD is not inevitably manifested as a proliferative lesion. When the gill tissue was cultured on Cytophaga agar, large numbers of yellow pigmented bacteria were isolated from all fish. These were identified as Flavobacterium and Flexibacter/Cytophaga using biochemical test methods. Bath treatment of surviving fish with nifurpirinol halted further mortalities.
\end{abstract}

\section{INTRODUCTION}

Bacterial gill disease (BGD) is a common disease of intensively cultured fish, especially of juvenile salmonids, but various nonsalmonids can also be affected. The disease is assumed to be stress mediated but the precise conditions under which it develops have not been identified. Although the genus Flavobacterium is frequently implicated in outbreaks (Kimura et al. 1978, Wakabayashi et al. 1980, Farkas 1985), no one specific agent is consistently isolated (Amend 1982). From a diagnostic viewpoint there are very few reports, if any, which document both the bacteriology and the histopathology of naturally occurring outbreaks of BGD and the disease has never been reported in goldfish Carassias auratus L. This communication therefore, describes the histopathology of 3 naturally occurring outbreaks of BGD in goldfish and the bacteriology of the yellow pigmented bacteria associated with them.

\section{MATERIALS AND METHODS}

History. Approximately 100 juvenile goldfish (ca 4 to $6 \mathrm{~cm}$ fork length) were purchased as food for larger carnivorous fish from a local pet store. The fish were transported to our laboratory in the original shipping water and placed into a $100 \mathrm{l}$ aquarium receiving nonchlorinated municipal tap water $\left(10^{\circ} \mathrm{C}\right)$ and supple- mental aeration. At this time the fish displayed flared opercula and laboured ventilation, and over the following $24 \mathrm{~h}$ half the fish died. Survivors were either lying at the bottom of the tank gasping or were gathered at the surface near the column of air bubbles. Ten moribund fish, labelled Outbreak A, were taken for examination. All had flared opercula, hyperaemic and swollen gill tissue, and excess mucus production. Scrapings of the gills were taken and examined microscopically. Large numbers of thin, filamentous bacteria were present on the surface of the gill epithelium but otherwise the branchial architecture appeared normal. Bacteriological samples were obtained by individually swabbing the second gill arch of 4 fish, streaking these onto Cytophaga agar (CA) containing $1.5 \%(\mathrm{w} / \mathrm{v})$ agar (1.5\% CA) (Anacker \& Ordal 1959) and incubating them aerobically at $20^{\circ} \mathrm{C}$ for $4 \mathrm{~d}$. The most common isolates recovered from each fish were subcultured onto CA with $0.9 \%$ agar $(0.9 \% \mathrm{CA})$ for further identification. Six fish were sampled for histopathology.

Two weeks after purchasing the first lot of fish, the pet store submitted an additional 5 moribund goldfish from a separate shipment of fish from the same commercial wholesaler. These fish (Outbreak B) presented clinical signs identical to those described in Outbreak A. Bacteriological samples were obtained from 3 fish as described above and the remaining fish were sampled for histopathology.

Outbreak C occurred ca 4 mo later with clinical signs 
similar to the first 2 outbreaks. Five moribund fish from the same store were submitted for examination. Two of these were individually sampled for hacteriology by aseptically removing the gill tissue from the left side of each fish. The tissue was weighed, placed in a plastic bag containing $5 \mathrm{ml}$ of sterile phosphate buffered saline (PBS; $\mathrm{pH} 7.4$ ) and manually crushed until only the cartilaginous arches remained. Serial 10 -fold dilutions of the samples were prepared and $20 \mu \mathrm{l}$ aliquots were plated onto $1.5 \% \mathrm{CA}$ and incubated as above. For each fish, the total number of bacterial colony forming units (CFUs) per $g$ of gill tissue and the number of yellow pigmented bacteria (YPB) recovered were determined. The 2 most common YPB colony types isolated from this outbreak were characterized as described tor the earler outbreaks. The remaining tish were taken for histopathology.

Histology. A total of 11 fish from the 3 outbreaks were taken for histopathology. They were placed in Bouin's fixative for $24 \mathrm{~h}$, sectioned in the mid-sagittal plane and routinely processed to paraffin for $\mathrm{H} \& \mathrm{E}$ staining. One gill arch from each fish from Outbreak $\mathrm{C}$ was also taken and fixed in $2.5 \%$ glutaraldehyde in a cacodylate buffer (total osmolality ca $320 \mathrm{mOsm}$ ) at $4{ }^{\circ} \mathrm{C}$. The tissue was subsequently post-fixed in $1 \%$ osmium tetroxide, dehydrated in graded alcohol and embedded in plastic. One micron sections were stained with toluidene blue and viewed with the light microscope.

Bacteriology. Further characterization of the bacteria was based on the criteria of Holmes et al. (1984). The following characteristics were examined; Gram reaction, cell morphology, flagellar and gliding motility, presence of flagella, fermentation in glucose $\mathrm{O}-\mathrm{F}$ medium, catalase and cytochrome oxidase production and penicillin susceptibility. The American Type Culture Collection strain ATCC 35036 (Flavobacterium sp.) recovered from salmonid BGD was used as a reference for all tests (Wakabayashi et al. 1980). Gram reaction and cell morphology were determined using 24 to 48 h Cytophaga broth (CB) cultures incubated at $20^{\circ} \mathrm{C}$ on a rotary shaker (100 RPM). Flagellar motility was determined by inoculating commercially available semi-solid media (Difco) while gliding motility was determined according to the method of Henrichson (1972) using a modified chamber culture technique (Reichenbach \& Dworkin 1981). A thin layer of molten $0.9 \%$ CA was applied to a sterile coverslip, spot inoculated, mounted inverted on a glass slide and incubated at $20^{\circ} \mathrm{C}$ for a maximum of $5 \mathrm{~d}$. The chambers were examined daily using phase contrast microscopy. The presence of a micromorphological pattern (ie. highly organized whirls and bands of cells in which the movement is continuous and follows the longitudinal axis of the cells) was considered a positive result. The presence of flagella was tested by suspending several colonies from a $48 \mathrm{~h} 1.5 \%$ CA plate culture in $1.0 \mathrm{ml}$ of PBS. A drop was placed on $3 \mathrm{~mm}$ coated grids for $30 \mathrm{~s}$, stained for $10 \mathrm{~s}$ using $2 \%$ phosphotungstic acid (pH 7.5) and examined in a transmission electron microscope. Escherichia coli and Aeromonas salmonicida were used as positive and negative controls, respectively. Penicillin susceptibilty was determined using a single $3 \mathrm{~mm}$ commercially available antibiotic disc (10 U, Becton Dickinson, Mississauga, Ontario, Canada) on freshly poured $1.5 \%$ CA plates seeded with the isolate and incubated at $20^{\circ} \mathrm{C}$. Susceptibility to penicillin was considered positive if a zone of inhibition was evident after $5 \mathrm{~d}$ of incubation.

The ability of the isolates to grow at $5,10,20,25,30$ and $37^{\circ} \mathrm{C}$ was examined with incubation periods ranging from 7 to $28 \mathrm{~d}$. Tolerance to $\mathrm{NaCl}$ was determined by inoculating $\mathrm{CB}$ containing $0,0.05,0.1,0.2,0.5,1.0$, 2.0 or $5.0 \% \mathrm{NaCl}$. The ability to produce hydrogen sulphide from thiosulphate (TSI), indole in tryptone broth, and the ability to reduce nitrate were also examined. Anaerobic growth was tested by incubating $\mathrm{CB}$ cultures for $21 \mathrm{~d}$ in an anaerobic jar (GasPak, BBL). Starch and casein hydrolysis were tested using $1.5 \%$ CA containing $1 \%$ potato starch or $15 \%$ skim milk powder $(\mathrm{w} / \mathrm{v})$ incubated at $20^{\circ} \mathrm{C}$ from 7 to $21 \mathrm{~d}$. After incubation, the starch plates were flooded with Gram's iodine. Cellulose degradation was determined by adding a sterile strip of Whatman No. 1 filter paper to a freshly seeded CB culture and incubated for $30 \mathrm{~d}$ at $20^{\circ} \mathrm{C}$. Complete disintegration of the filter paper was considered a positive reaction. Gelatin liquefaction was determined using commercially available media (Difco). The presence of flexirubin-like pigments in the cell wall of the goldfish isolates was identified by flooding a colony with $20 \% \mathrm{KOH}$ (Reichenbach et al. 1981). If present, the colony color would shift from yellow to red or brown almost instantly.

In vitro susceptibility to nifurpirinol was tested by inoculating $50 \mu \mathrm{l}$ of a $24 \mathrm{~h} \mathrm{CB}$ culture of each isolate, into $1 \mathrm{mg} 1^{-1}$ of (filter sterilized, $0.45 \mu \mathrm{m}$ ) nifurpirinol in $\mathrm{CB}$. The tubes were incubated at $20^{\circ} \mathrm{C}$ for $3 \mathrm{~d}$.

Serology. A slide agglutination technique was used to examine the antigenic relationship between the goldfish isolates and Flavobacterium sp. (ATCC 35036) recovered from salmonid fish with BGD (Wakabayashi et al. 1980). Anti-ATCC 35036 serum was kindly provided by Dr H. Wakabayashi (1024 titre). A plate of $1.5 \% \mathrm{CA}$ was inoculated with $1.0 \mathrm{ml}$ of a $24 \mathrm{~h} \mathrm{CB}$ culture and incubated at $20^{\circ} \mathrm{C}$ for $3 \mathrm{~d}$, after which the cells were harvested and suspended in $1.0 \mathrm{ml}$ of PBS $(\mathrm{pH} 7.4)$. Equal $20 \mu \mathrm{l}$ aliquots of the cell suspension $\left(10^{8}\right.$ cells $\mathrm{ml}^{-1}$ ) and serum (either full strength or diluted $1: 10$ ) were mixed on a glass slide and allowed to react for $2 \mathrm{~min}$. The slides were gently rocked back and forth 
for an additional $30 \mathrm{~s}$ before interpretation. Nonimmune rabbit serum was used as a control.

\section{RESULTS}

\section{Histopathology}

The most consistent histological finding among all outbreaks was the presence of large numbers of filamentous Gram negative bacteria associated with the surface of the gill tissue. Fish from Outbreaks A and $B$ displayed changes considered typical of an acute outbreak of BGD - a mild to moderate swelling of individual chloride and epithelial cells, mild to moderate interlamellar epithelial hyperplasia, and the presence of filamentous bacteria associated with the surface of the lamellar epithelium (Fig. 1), often in association with organic debris. Lamellar fusion or filamental clubbing was not evident in the sections examined Several of the fish from Outbreak $\mathrm{C}$ displayed a more necrotizing response to the bacteria which included varying degrees of vacuolar degeneration, necrosis, and sloughing of individual epithelial and chloride cells (Fig. 2). In several instances, filamentous bacteria were also observed within these necrotic and degenerating cells. A mild inflammatory infiltrate was evident in the branchial interstitium.

Another finding was the presence, in a few fish, of low numbers of circular, basophilic bodies present intracellularly within gill epithelial and chloride cells. A minimal host response was associated with these organisms (Fig. 1) which were considered to be
Chlamydia-like. Similarily, low numbers of Chilodonella and Costia protozoa were seen in the gills of a few fish, mainly from Outbreak A. With the exception of occasional internal metazoan parasites, other tissues from all fish appeared normal.

\section{Bacteriology}

The total number of CFUs per $g$ of gill tissue of the 2 fish from Outbreak $C$ was $4.5 \times 10^{6}$ and $1.2 \times 10^{7}$, with the yellow pigmented bacteria (YPB) constituting 69 and $61 \%$ of the total number recovered, respectively. The remaining isolates were not identified but they were mainly Gram-negative, oxidase-positive motile organisms. Large numbers of YPB colonies were also recovered from all fish in Outbreaks $A$ and $B$. The characteristics of 11 strains plus the reference strain, ATCC 35036, are summarized in Table 1. All isolates were slender, Gram-negative rods measuring 0.6 to $0.8 \times 4.0$ to $7.0 \mu \mathrm{m}$. Two of the strains (B315-A2, B601-A) were more filamentous in nature and measured 8 to $12 \mu \mathrm{m}$. All were cytochrome oxidase and catalase positive, nonfermentative in $\mathrm{O} / \mathrm{F}+$ glucose medium. Two distinct groups of YPB were recovered, with one group forming colonies which spread across the surface of both the $0.9 \%$ and $1.5 \%$ agar, while the other group did not. Several of the spreading colonies would overgrow the surface of a freshly poured $0.9 \%$ CA plate $(82 \mathrm{~mm}$ diam.) in $3 \mathrm{~d}$. Three of the 6 isolates recovered from Outbreak A formed spreading colonies. All isolates were slow growing on $1.5 \% \mathrm{CA}$ with colony size ranging from 2 to $7 \mathrm{~mm}$ in 2 to $3 \mathrm{~d}$; they had a flat,
Fig. 1 Carassias auratus. Interlamellar epithelial hyperplasia with relatively large numbers of filamentous bacteria associated with surface of gills of goldfish from Outbreak A. Circular, refractile bodies present within the epithelial and chloride cells are the Chlamydia-like organisms (arrow). $\mathrm{H} \& \mathrm{E}_{\text {; }}$ $\times 400$

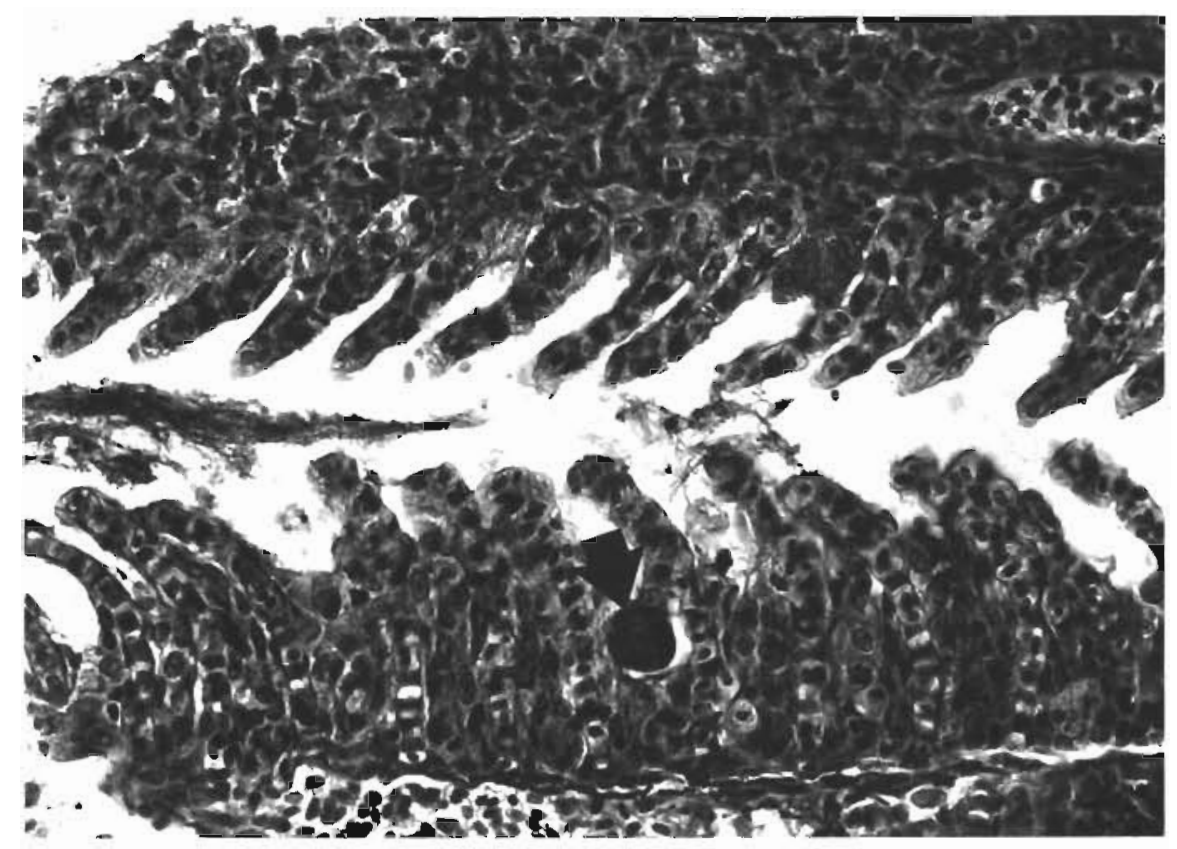




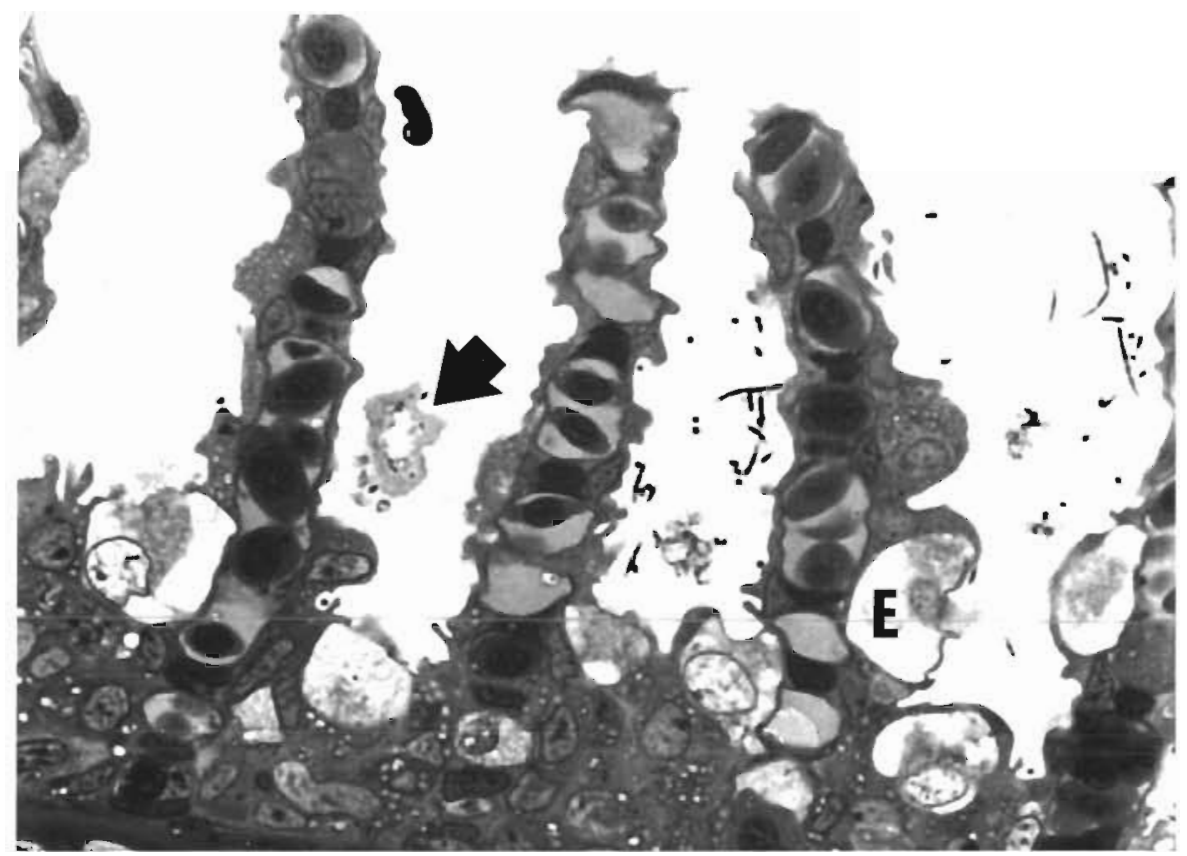

Fig. 2. Carassias auratus. High power photomicrograph of lamellae of gills of goldfish from Outbreak C showing necrotizing response to filamentous bacteria. Varying degrees of vacuolar degeneration of individual epithelial and chloride cells (E) and sloughing (arrow) are also evident. Epon; $\times 1000$

Table 1. Summary of morphological, physiological and biochemical characteristics of filamentous yellow pigmented bacteria recovered from 3 naturally occuring outbreaks of BGD in goldfish. +: positive or present; - : negative or absent; Col. Spr.: colonial spreading; Glid. mot.: gliding motility; Pen. sens.: penicillin sensitivity; Flex. pig.: flexirubin-like pigments; Agglut.: agglutination with anti-ATCC 35036 serum; ND: not done

\begin{tabular}{|c|c|c|c|c|c|c|c|c|c|c|c|c|c|c|}
\hline \multirow{2}{*}{$\begin{array}{l}\text { Out- } \\
\text { break }\end{array}$} & \multirow{2}{*}{ Strain } & \multirow{2}{*}{$\begin{array}{l}\text { Col. } \\
\text { spr. }\end{array}$} & \multirow{2}{*}{$\begin{array}{l}\text { Gilid. } \\
\text { mot. }\end{array}$} & \multirow{2}{*}{$\begin{array}{c}\text { Growth } \\
5-30\end{array}$} & \multirow{2}{*}{$\begin{array}{l}\left({ }^{\circ} \mathrm{C}\right) \\
37\end{array}$} & \multirow{2}{*}{$\begin{array}{l}\text { Pen. } \\
\text { sens. }\end{array}$} & \multirow{2}{*}{$\begin{array}{l}\text { Flex. } \\
\text { pig. }\end{array}$} & \multirow{2}{*}{$\begin{array}{l}\text { Reduce } \\
\text { nitrate }\end{array}$} & \multicolumn{4}{|c|}{ Growth in $(\% \mathrm{NaCl})$} & \multirow{2}{*}{$\begin{array}{c}\text { Agglut. } \\
\text { anti- } \\
35036\end{array}$} & \multirow{2}{*}{$\begin{array}{c}\text { Nifur- } \\
\text { pirinol } \\
\text { sensitivity }\end{array}$} \\
\hline & & & & & & & & & 0 & 1.0 & 2.0 & 5.0 & & \\
\hline \multirow[t]{6}{*}{ A } & $\mathrm{B} 315-\mathrm{A} 2$ & - & - & + & + & + & - & + & + & + & + & - & - & + \\
\hline & B315 B & - & + & t & - & - & + & - & + & + & + & - & - & + \\
\hline & B315 C & + & + & + & - & + & - & + & t & + & + & - & - & - \\
\hline & B315 D2 & - & - & + & - & - & + & + & + & + & + & - & + & - \\
\hline & B315 E1 & + & + & + & - & - & + & + & + & + & + & - & - & - \\
\hline & B315 F & + & + & + & $=$ & - & + & - & + & + & + & - & - & - \\
\hline \multirow[t]{3}{*}{ B } & B322-A & - & + & + & - & - & + & - & + & + & + & - & - & - \\
\hline & B322 B & - & + & + & - & - & + & - & + & + & + & - & - & + \\
\hline & B322 D & - & - & + & + & - & - & - & + & + & + & - & - & - \\
\hline \multirow[t]{2}{*}{ c } & B601-A & - & - & + & - & - & - & + & + & + & - & - & - & + \\
\hline & $\mathrm{B} 601 \mathrm{~B}$ & - & - & + & - & - & - & + & + & + & - & - & - & - \\
\hline ATCC & 35036 & - & - & + & - & + & - & - & + & - & - & - & t & ND \\
\hline
\end{tabular}

rough, translucent appearance and thin filamentous margins radiating outwards. The remaining isolates formed nonspreading colonies and were slower growing with smooth, circular, convex, translucent colonies from 0.5 to $1.0 \mathrm{~mm}$ diam. after $4 \mathrm{~d}$. Outbreaks B and C yielded only nonspreading isolates (colony size ca $1.0 \mathrm{~mm}$ ); they were similar in appearance to the nonspreading isolates recovered from Outbreak A.

All spreading isolates and 3 of the nonspreading strains displayed gliding motility based on the criteria of Henrichson (1972). None of the isolates possessed flagella. All grew at 5, 10, 20, 25 and $30^{\circ} \mathrm{C}$ with optimum growth from 20 to $25^{\circ} \mathrm{C}$ in $\mathrm{CB}$. Two NS isolates were able to survive at $37^{\circ} \mathrm{C}$. None of the isolates produced indole, $\mathrm{H}_{2} \mathrm{~S}$ from thiosulphate or grew anaerobically. Approximately half of the isolates failed to reduce nitrate and the majority were resistant to penicillin $\left(10 \mathrm{U} \mathrm{disc}^{-1}\right)$. Variable growth was recorded in $\mathrm{CB}$ containing $\mathrm{NaCl}$. The reference strain grew only in the absence of salt. All hydrolyzed gelatin, starch, and casein and, while many isolates colonized the filter paper, none degraded cellulose. Approxi- 
mately half tested positive for the presence of flexirubin-like pigments. The isolates varied in their sensitivity to nifurpirinol.

\section{Serology}

One isolate (B315-D2) and the reference strain gave a positive slide agglutination result with anti-A.TCC 35036 serum.

\section{Identification}

Based on the criteria of Holmes et al. (1984), 55\% (6/ 11) of the strains were identified as Flexibacter/ Cytophaga while the remaining strains resembled Flavobacterium. Interestingly, 25\% (3/12) of the isolates (including the reference strain) gave aberrant penicillin susceptibility reactions. Considerable biochemical variation was apparent among the YPB recovered from $\mathrm{BGD}$ in goldfish. Although 1 isolate agglutinated with anti-serum to the reference strain, it is felt that none of these isolates shared similar biochemical characteristics.

\section{DISCUSSION}

The diagnosis in Outbreaks A and B was an acute proliferative branchitis, while Outbreak $C$ was characterized by a mild necrotizing branchitis with subsequent epithelial degeneration and sloughing. Based on the primary diagnosis of $B G D$, the surviving fish from all outbreaks were treated with a bath of $1.0 \mathrm{mg} \mathrm{l}^{-1}$ nifurpirinol (Prefuran, Argent Chemicals, Redmond, WA, USA) for $60 \mathrm{~min}$ for 3 consecutive days, which halted further mortalities.

Using an isolate from Outbreak C (B601-A) and the technique of Wakabayashi et al. (1980), attempts to experimentally reproduce the disease were unsuccessful. A causal relationship between the gill disease and the filamentous bacteria was not established but more than one organism may have been responsible for the disease. The bacteria are considered to be much more important than any of the associated parasites, which were present only in low numbers and which were not consistently seen in all fish. Whether the goldfish had subclinical BGD at the time of shipment or whether they developed it during or after transport is unknown.

These findings show that BGD is not inevitably manifested as a proliferative lesion, and that some necrosis and sloughing of epithelium can be found, possibly as a prelude to subsequent hyperplasia. It must be emphasized however, that the extent and severity of the necrosis was extremely mild by comparison with, for example columnaris disease. Although a possible virulence mechanism for hyperplasia has been proposed (Kudo \& Kimura 1983), this now seems like an unnecessarily complicated hypothesis to invoke. Necrosis by itself would normally be expected to lead to many of the histological changes seen in BGD (for example hyperplasia and fusion), especially if the organisms persist. The presence of bacteria within degenerating epithelial and chloride cells also suggests the possibility of systemic involvement and impaired osmoregulation.

The strain ATCC 35036 (Flavobacterium sp.), recovered from salmonid BGD in Japan and Oregon (Wakabayashi et al. 1980), was employed as a reference strain because biochemically and antigenically similar isolates were recovered from intensively cultured cyprinids (Farkas 1985). One of our isolates was antigenically related to this reference strain but was not biochemically similar. The reference strain was extremely sensitive to salt, however, and it is possible that the technique employed for bacterial recovery (maceration of gill tissue in saline) may have selected for salt tolerant organisms. On the other hand, an indirect fluorescent antibody technique on the gills of 1 fish from Outbreak C, using anti-ATCC 35036 serum, failed to demonstrate antigenically similar organisms associated with the gills. Moreover, direct swabbing of the gills from Outbreaks A or B failed to recover biochemically or antigenically similar bacteria. Both of these techniques should have permitted the detection of reference strain-like bacteria, had they been present.

Currently it is suggested that an extremely diverse group of yellow pigmented bacteria (YPB) is associated with filamentous bacterial diseases including BGD (Shotts et al. 1986). These bacteria include members of the genera Flexibacter, Cytophaga, and Flavobacterium (Anderson \& Conroy 1969, Bullock 1972, Kimura et al. 1978, Wakabayashi et al. 1980, Piper et al. 1982. Schachte 1983, Farkas 1985). It also now appears that a similarly diverse group of YPB is associated with $\mathrm{BGD}$ in goldfish, as these isolates fall within this broad taxonomic categorization, based on the current methods of identification (Holmes et al. 1984).

Acknowledgements. The Fish Pathology Laboratory is supported in part by the Ontario Ministry of Agriculture and Food.

\section{LITERATURE CITED}

Amend, D. F. (1982). Columnaris (Flexibacter columnaris) disease of freshwater fishes and a brief review of other flexibacterial diseases of fish. In: Anderson, D. P., Dorson, M., Dubourget, Ph. (eds.) Les antigenes des micro-organismes pathogenes des poissons (Antigens of fish pathogens: development and production for vaccines and serodiagnostics). Collection Fondation Marcel Merieux, Lyon, France. p. 139-151 
Anacker, R. L., Ordal, E. J. (1959). Studies on the myxobacterium Chondrococcus columnaris I. Serological typing. J Bacteriol 78: 25-32

Anderson, J. I. W., Conroy, D. A. (1969). The pathogenic myxobacteria with special reference to fish diseases. J. appl. Bact. 32: 30-39

Bullock, G. L. (1972). Studies on selected myxobacteria pathogenic for fishes and on bacterial gill disease in hatch ery reared salmonids. United States Department of the Interior, Fish and Wildife Service, Technical Report 60, Washington, D. C

Farkas, J. (1985). Filamentous Flavobacterium sp. isolated from fish with gill diseases in cold water. Aquaculture 44 $1-10$

Henrichson, J. (1972). Bacterial surface translocation: a survey and a classification. Bact. Rev. 36: 478-503

Holmes, B. H., Owen, R. J., McMeekin, T A. (1984). Genus Flavobacterium Bergey, Harrison, Breed, Hammer and Huntoon 1923, 97 AL. In: Krieg, N. R., Holt, J. C. (eds.) Bergey's Manual of Systematic Bacteriology, Vol. 1. Williams and Wilkens, Baltimore, Maryland p. 353-361

Kimura, N, Wakabayashi, H., Kudo, S. (1978). Studies on bacterial gill disease in salmonids - I. Selection of bacterium transmitting gill disease. Fish Path. 12: 233-242

Kudo, S., Kimura, N. (1983). Extraction of a hyperplasia inducing factor. Bull. Jap. Soc. scient. Fish. 49: 1777-1782

Piper, R. G., McElwain, I. B., Orme, L. E., McCraren, J. P.,
Fowler, L. G., Leonard, J. R. (1982). Fish Hatchery Management. United States Department of the Interior. Washington, D. C.

Reichenbach, H., Dworkin, M. (1981). Introdruction to the gliding bacteria. In: Starr, M. P., Stolp, H., Truper, H. G. Balows, A., Schlegel, H. G. (eds.) The prokaryotes: a handbook on habitats, isolation and identification of bacteria. Springer-Verlag, Berlin, Heidelberg. p. 315-327

Reichenbach, H., Kohl, W., Achenbach, H. (1981). The flexifubin-type pigments, chemosystematically useful compounds. In: Reichenbach. $H_{1}$, Weeks, O. B. (eds.) Gesellschaft für Biotechnologische Forschung mbH. Braunschweig-Stockheim. Proceedings of the International Symposium on Yellow Pigmented Gram-Negative Bacteria of the Flavobacterium-Cytophaga Group, 8 to 11 July, 1980. Verlag Chemie, Deerfield Beach, Florida

Schachte, J. H. (1983). Bacterial gill disease. In: Meyer, F. P., Warren, J. W., Carey, T G. (eds.) A Guide to Integrated Fish Heaith Management in the Great Lakes Basin. Creat Lakes Fisheries Commission, Ann Arbor, Michigan, p. $181-184$

Shotts, E. B., DelCorral, L. F., Hsu, T L. (1986). Yellow pigmented bacteria associated with fish diseases. Proc. int. Ass. Aquat. An. Med. 1 (3): 116-119

Wakabayashi, H., Equsa, S., Fryer, J. L. (1980). Characteristics of filamentous bacteria isolated from a gill disease of salmonids. Can. J. Fish. Aquat. Sci. 37: 1499-1504 